\title{
Ammonia as hydrogen carrier for realizing distributed on-site refueling stations implementing PEMFC technology
}

\author{
,Alessandra Perna ${ }^{1}$, Mariagiovanna Minutillo ${ }^{2}$,Simona Di Micco ${ }^{2,}$, Viviana Cigolotti ${ }^{3}$ and \\ Adele Pianese ${ }^{2}$ \\ ${ }^{1}$ University Cassino and Southern Lazio, Cassino, Italy \\ ${ }^{2}$ University of Naples "Parthenope", Naples, Italy \\ ${ }^{3}$ ENEA - Italian National Agency for New Technologies, Energy and Sustainable Economic \\ Development, Naples, Italy
}

\begin{abstract}
Abstract. Ammonia is a particularly promising hydrogen carrier due to its relatively low cost, high energy density, its liquid storage and to its production from renewable sources. Thus, in recent years, great attention is devoted to this fuel for realizing next generation refueling stations according to a carbon-free energy economy. In this paper a distributed onsite refueling station $(200 \mathrm{~kg} /$ day of hydrogen filling 700-bar HFCEVs (Hybrid Fuel Cell Electric Vehicles) with about $5 \mathrm{~kg}$ of hydrogen in $5 \mathrm{~min}$ ), based on ammonia feeding, is studied from the energy and economic point of views. The station is designed with a modular configuration consisting of more sections: i) the hydrogen production section, ii) the electric energy supplier section, iii) the compression and storage section and the refrigeration/dispenser section. The core of the station is the hydrogen production section that is based on an ammonia cracking reactor and its auxiliaries; the electric energy demand necessary for the station operation (i.e. the hydrogen compression and refrigeration) is satisfied by a PEMFC (Proton-Exchange Membrane Fuel Cell) power module. Energy performance, according to the hydrogen daily demand, has been evaluated and the estimation of the levelized cost of hydrogen $(\mathrm{LCOH})$ has been carried out in order to establish the cost of the hydrogen at the pump that can assure the feasibility of this novel refueling station.
\end{abstract}

\section{Introduction}

The transition from a hydrocarbon-based mobility to a hydrogen-based mobility requires a deep analysis on several techno-economic issues, ranging from the vehicles designing to the hydrogen production and distribution in the refueling station [1,2]. This last issue, that is crucial for the development of the market of hydrogen vehicles, requires the evaluation of the most promising hydrogen carriers that assure relatively low costs, high energy density and sustainability. Several candidates as hydrogen carrier are under exploration and liquid ammonia has recently been considered as a highly capable carrier owing to its high gravimetric and volumetric hydrogen storage capacities of $17.7 \mathrm{wt} \%$ and $120 \mathrm{~g} / \mathrm{L}$ (materialsbased) [3]. Moreover, ammonia is relatively inexpensive, easy to store and to transport, thanks to its high energy volume density $\left(13.77 \mathrm{MJ} / \mathrm{L}\right.$ at $20^{\circ} \mathrm{C}$ and 8.6 bars).

In the present study an on-site refueling station, based on the ammonia as primary source, is studied from the energy and economic point of views. A high hydrogen content stream is

* Corresponding author: simona.dimicco@uniparthenope.it 
produced through the ammonia cracking and this stream is used both for satisfying the daily hydrogen demand of the station $(200 \mathrm{~kg} /$ day) and the fuel requirement of a PEMFC power unit that supplies electric power demand of the station.

\section{Hydrogen demand and storage strategy}

The refueling station capacity is an important factor in determining the levelized cost of hydrogen; as a matter of fact, if the station capacity is low, the capital and operation costs, being distributed over small amount of distribute hydrogen, are proportionally high. However, the choice of the station capacity depends on the number of HFCEVs in the market. For that reason, present-day stations have small capacities. In this study a small-medium station capacity of $200 \mathrm{~kg} /$ day is considered.

The hourly hydrogen demand and the number of refueled cars are illustrated in figure 1 [4]. The knowledge of this trend is fundamental for evaluations on the sizing of storage tanks.

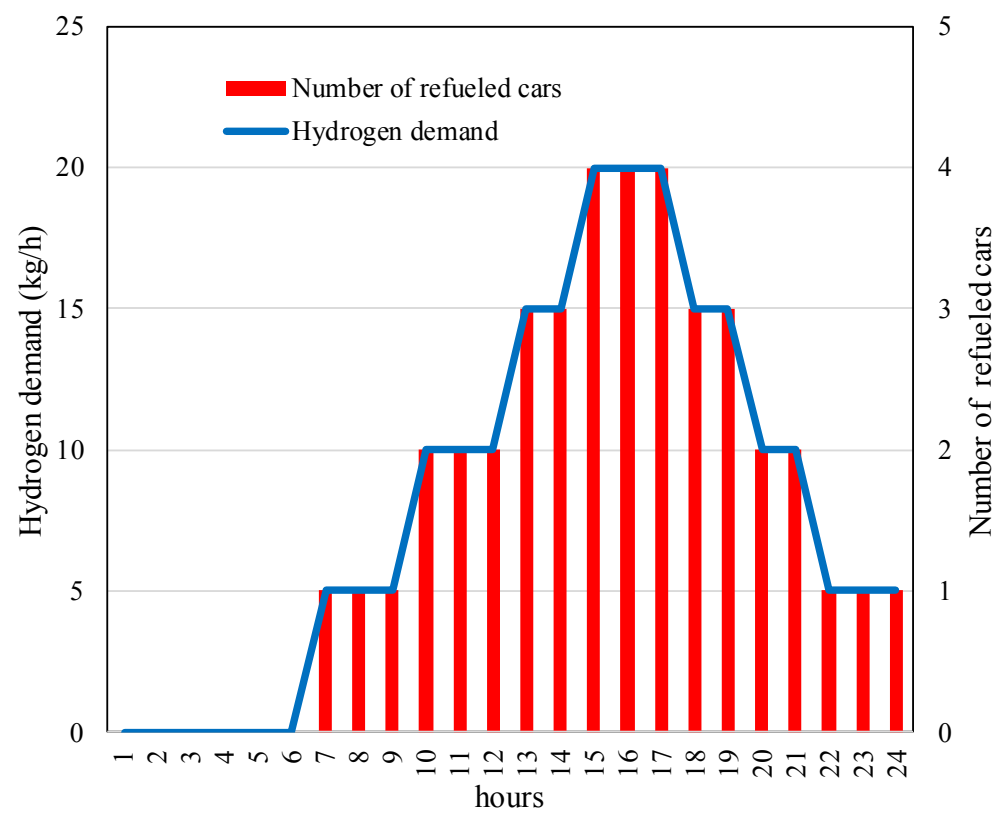

Fig.1. Hydrogen Refueling Station hourly demand

\section{Plant design and modelling}

The proposed on-site hydrogen refueling station (HRS) is based on ammonia cracking. It consists of the ammonia cracking/adsorption units, the membrane separation unit, the compression and storage unit, the refrigeration unit and the hydrogen dispensing unit. The electricity demand for the station operation is satisfied by a PEM fuel cell unit fed by part of the product hydrogen. The hydrogen production capacity has been selected in accordance with a middle-term mobility scenario that corresponds to $200 \mathrm{~kg} / \mathrm{day}$. This capacity 
determines directly the size of each component of the station and the electric energy demand that has to be supplied by the PEMFC power unit.

The plant has been modeled in Aspen Plus ${ }^{\mathrm{TM}}$ environment by following a modular architecture in which each sub-model is conceived as a plant section that interacts with components by means of mass and energy fluxes. The refrigeration unit and the hydrogen dispensing unit are not included in the model, but their energy requirements are separately calculated. This choice is due to the different operational time of the hydrogen production and storage plant (24 hours per day) compared to the operational time of the refrigeration and dispensing units (200 minutes per day). Therefore, in order to not over-size the plant, the electric power consumption of these units is supplied by the grid.

Figure 2 shows the flowsheet of the plant model. The ammonia (1), stored in liquid state at 8.7 bar, is vaporized and superheated in the heat exchanger $\mathrm{HE} 1\left(57^{\circ} \mathrm{C}\right)$ and $\mathrm{HE} 2\left(279^{\circ} \mathrm{C}\right)$, respectively, and, after expanding down to the atmospheric pressure through the valve, is sent to the cracking reactor where it is decomposed into nitrogen and hydrogen at $550^{\circ} \mathrm{C}$.

The gas mixture (5) is cooled up to $454^{\circ} \mathrm{C}$ in the exchanger $\mathrm{HE} 3$ and to $67^{\circ} \mathrm{C}$ in the exchanger $\mathrm{HE} 2$ before entering the NH3 adsorber in which the residual ammonia (ppm) is removed. Then, the hydrogen/nitrogen mixture is separated in two fluxes: the first one (10) is sent to the compressor C1, while the second one (9) feeds the PEMFC power unit. The required heat for the NH3 cracking reaction is supplied by the exhausts (19) exiting the catalytic burner (CB). The catalytic burner is fed with the PEMFC exhausts (17), the purge gas (16) from the Pd-M membrane unit and air (23) that is pre-heated in HE4 by the exhausts (20) exiting the cracking reactor. In order to reach the operating conditions (pressure and temperature) of the $\mathrm{Pd}-\mathrm{M}$ membrane unit, the stream (10) is compressed in the compressor C1 up to 4.4 bar (the membrane operating pressure in the feeding side) and heated at $400^{\circ} \mathrm{C}$ in $\mathrm{HE} 3$. The pure hydrogen (13) is cooled in the HE1 and is compressed up to 20 bar (C2), before to be sent to the hydrogen compression and storage section, consisting of 4 compression stages that realize a compression cascade system with 4 tanks at different pressure levels.

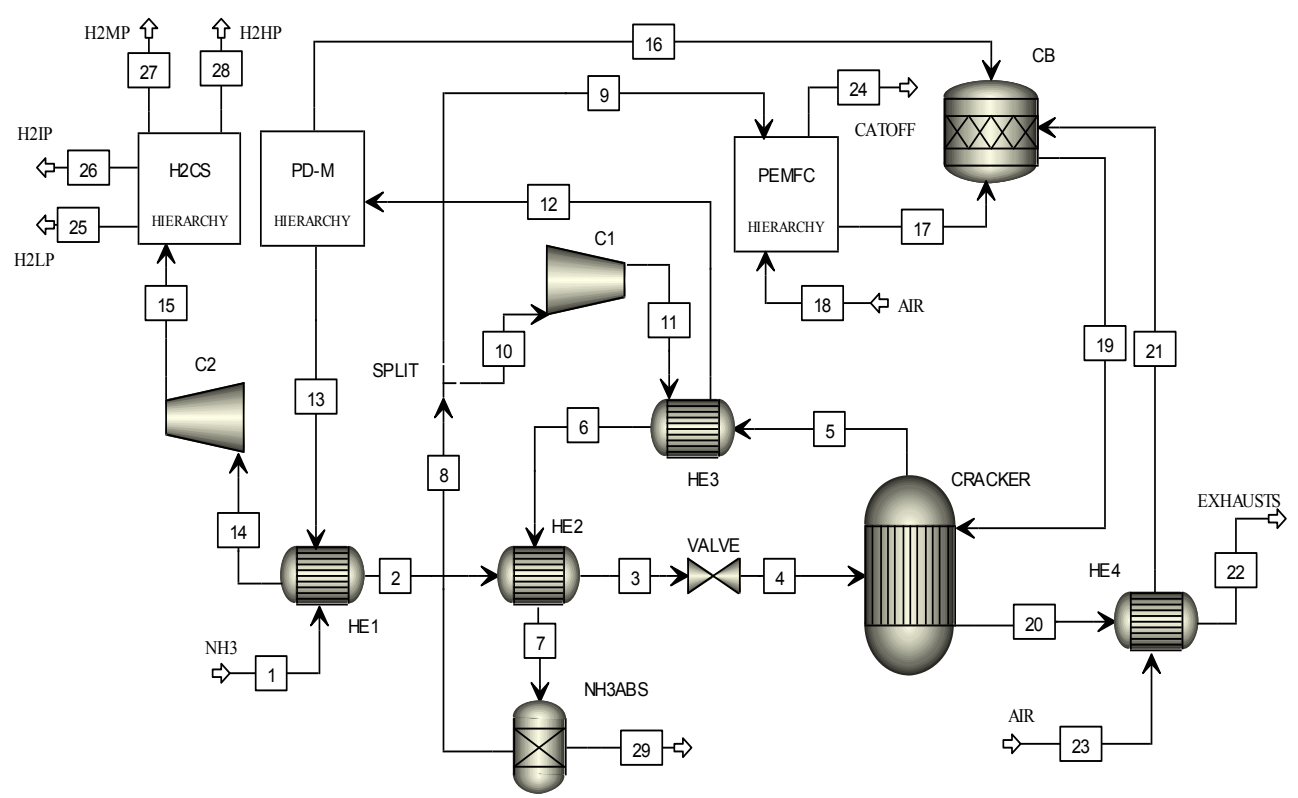

Fig.2.Flowsheet of the plant model 
The integrated model has been developed by using existing unit operation blocks such as compressor, heat exchanger, separator and chemical reactor and user defined blocks (Hierarchy block) where components not available in the Aspen Plus library are modeled by means of unit operation blocks and calculator blocks. Table 1 presents the description of the models used for simulating the components illustrated in the flowsheet. The Peng-Robinson cubic equation of state (EOS) has been applied to define and characterize the physical and chemical properties of all streams. This EOS can accurately describe both the liquid and vapor phase for $\mathrm{H} 2$ content systems in a wide range of pressure and temperature.

Table 1. Models description of the plant components

\begin{tabular}{|c|c|}
\hline $\begin{array}{c}\text { Plant } \\
\text { Components }\end{array}$ & Sub-model description \\
\hline Cracking reactor & $\begin{array}{l}\text { The ammonia cracking process is depending on the temperature and the catalyst. } \\
\text { At } 425^{\circ} \mathrm{C} \text { ammonia can be decomposed to hydrogen and nitrogen reaching } 98 \text { - } \\
99 \% \text { of conversion, and at temperatures above } 500^{\circ} \mathrm{C} \text { its decomposition can occur } \\
\text { without any catalysts [5] The cracking reaction is: } \\
\qquad 2 \mathrm{NH}_{3} \rightarrow 3 \mathrm{H}_{2}+\mathrm{N}_{2} \\
\text { The cracker is modeled by using the } R G i b b s \text { unit operator block where no reaction } \\
\text { kinetics are applied. The } R G i b b s \text { uses the Gibbs free energy minimization to } \\
\text { calculate the equilibrium and does not require specified reaction stoichiometry. } \\
\text { The Gibbs free energy of the reaction system (for } k \text { species) is: } \\
\qquad G^{t}=\sum_{i=1}^{k} n_{i} \cdot \mu_{i} \\
\text { where } n_{i} \text { is the moles number of species } i \text {, and } \mu_{i} \text { is its chemical potential. For } \\
\text { the WGSRs, the methane eventually present in the reactant flow is considered as } \\
\text { an inert. }\end{array}$ \\
\hline $\begin{array}{l}\text { PEMFC unit } \\
\text { (PMFC) }\end{array}$ & $\begin{array}{l}\text { The model of the PEMFC power unit is based on the empirical equation } \\
\text { proposed by Kim et al. [6] to forecast the cell voltage: } \\
\qquad V_{\text {cell }}=V_{0}-b \cdot \ln (\mathrm{J})-R \cdot J-m \cdot \exp (-n \cdot J) \\
\text { where } V_{0}(\mathrm{~V}) \text { is the reversible cell potential, } J \text { is the current density }\left(\mathrm{A} / \mathrm{cm}^{2}\right), b \\
(\mathrm{~V} / \mathrm{dec}) \text { is the Tafel slope, } R(\Omega \mathrm{cm} 2) \text { is the ohmic resistance, } m(\mathrm{~V}) \text { and } n \\
(\mathrm{~cm} / \mathrm{A}) \text { are parameters that account for the mass transport overpotential. These } \\
\text { coefficients have been calculated by applying a regression technique on the } \\
\text { experimental data obtained by testing a water-cooled PEMFC stack fed with } \\
\text { hydrogen }\left(\mathrm{H}_{2} \text { concentration equal to vol } 75 \% \text {, balanced with inert gases }\right) \text { and } \\
\text { operated at } 67^{\circ} \mathrm{C}[7] \text {. The calculated values of the fitting parameters } V_{0}, b, R \text {, } \\
\text { are } 0.7018,0.0428,0.479 \text {, respectively, whereas m and n are set equal to zero. } \\
\text { By considering the cells number, the stacks number and the operating current, } \\
\text { the electric power generated is: } \\
\qquad W_{e l, P U}=N_{\text {stack }} \cdot n_{\text {cell }} \cdot V_{\text {cell }} \cdot I\end{array}$ \\
\hline $\begin{array}{l}\text { Pd-Membrane } \\
\text { (Pd-M) }\end{array}$ & $\begin{array}{l}\text { The membrane separation unit consists of multi-tube supported ceramic Pd-Ag } \\
\text { membrane [8]. The parameters that drive the hydrogen permeation through the } \\
\text { membrane are its concentration in the feeding gas, the operating temperature and } \\
\text { the pressure gradient between the feed and permeate sides. } \\
\text { The equations used to simulate the permeation process are reported in }[9,10] \text {. The } \\
\text { inputs to the model are the hydrogen recovery ratio (HRF) that is the ratio between } \\
\text { the permeate hydrogen (mol/s) and the hydrogen (mol/s) in the feed stream, the }\end{array}$ \\
\hline
\end{tabular}




\begin{tabular}{|c|c|}
\hline HIERARCHY & $\begin{array}{l}\text { feed and permeate sides pressures, the membrane thickness and operating } \\
\text { temperature. The outputs are the membrane total area, the amount of permeate } \\
\text { hydrogen }(\mathrm{mol} / \mathrm{s}) \text { and the retentate gas flow rate }(\mathrm{mol} / \mathrm{s}) \text { and composition. } \\
\text { The flow rate of the total permeated hydrogen }(\mathrm{mol} \mathrm{s}-1) \text { is: } \\
\qquad n_{H_{2}, \text { perm }}=J_{H_{2}, \text { perm }} \cdot A_{\text {perm }}=N_{m} N_{t} \cdot A_{\text {perm,tube }} \\
\text { where } J_{H_{2}, \text { perm }} \text { is the hydrogen permeation flux }[8] A_{\text {perm }}\left(\mathrm{m}^{2}\right) \text { is the permeation } \\
\text { area, } A_{\text {perm,tube }} \text { is the single tube permeation area, } N_{m} \text { the modules number and } N_{t} \\
\text { the number of tubes in each module. The Pd-Membrane unit is modeled by means } \\
\text { of a separator block and a Fortran block calculator in which the model equations } \\
\text { are implemented. }\end{array}$ \\
\hline $\begin{array}{l}\text { H2 Compression } \\
\text { and Storage } \\
\text { (H2CS) }\end{array}$ & $\begin{array}{l}\text { The compression and storage section has been modelled as a cascade system in } \\
\text { which there are more banks each of which have different pressures. Thus, in order } \\
\text { to assure different pressure levels, more reciprocating compressors are used. The } \\
\text { power required by each compressor is calculated through the first law of } \\
\text { thermodynamics in Eulerian form (by assuming the adiabatic operation) and by } \\
\text { applying the polytropic equation }\left(p \cdot v^{m}=\text { cost, where } m \text { is the exponent of the }\right. \\
\text { polytropic curve simulating the real compression process) between the initial and } \\
\text { final state as: } \\
\qquad W_{C}=\left.\dot{m}_{\text {stream }} \cdot \Delta h\right|_{\text {in }} ^{\text {out }}=\left.\dot{m}_{\text {stream }} \cdot c_{p, s t r e a m} \cdot \Delta T\right|_{\text {in }} ^{\text {out }} \\
\qquad=\dot{m}_{\text {stream }} \cdot c_{p, \text { stream }} \cdot T_{\text {in }} \cdot\left[\left(\frac{p_{\text {out }}}{p_{\text {in }}}\right)^{\frac{k-1}{k}} \cdot \frac{1}{\eta_{\text {pol }}}-1\right] \\
\text { In the above equation, } k \text { is the adiabatic index, } c_{p, H 2} \text { is the hydrogen constant } \\
\text { pressure specific heat, } T_{\text {in,i }}(\mathrm{K}), p_{\text {in, }} \text { and } p_{\text {out,i }} \text { are the inlet temperature and the inlet } \\
\text { and outlet pressures of each compressor }(i) \text {, respectively. The polytropic efficiency } \\
\eta_{p o l} \text { is assumed equal to } 80 \% \text {. The total power consumption is: } \\
\qquad W_{C}=\sum_{i} W_{C(i)}\end{array}$ \\
\hline $\begin{array}{l}\text { Heat exchangers } \\
\text { (HXs) }\end{array}$ & $\begin{array}{l}\text { The heat exchangers are modeled by using the HeatX that can perform shortcut } \\
\text { or detailed rating calculations for most types of two-stream heat exchangers. For } \\
\text { a two-stream exchanger the set of equations is: } \\
\qquad \begin{array}{l}Q=\dot{m}_{\text {cold }} \cdot \Delta h_{\text {cold }} \\
\qquad Q=\dot{m}_{\text {hot }} \cdot \Delta h_{\text {hot }} \\
\qquad Q=U \cdot A \cdot L M T D\end{array} \\
\text { where } \mathrm{U}\left(\mathrm{kW} / \mathrm{m}^{2} \mathrm{~K}\right) \text { is the heat transfer coefficient, A }\left(\mathrm{m}^{2}\right) \text { is the heat } \\
\text { exchange area and LMTD is the log-mean temperature difference. }\end{array}$ \\
\hline Compressor (C) & $\begin{array}{l}\text { This component is modeled by using the Compr unit operation block; the power } \\
\text { is calculated through the first law of thermodynamics in Eulerian form (by } \\
\text { assuming the adiabatic operation) and by applying the polytropic equation: } \\
\qquad W_{C}=\left.\dot{m}_{\text {stream }} \cdot \Delta h\right|_{\text {in }} ^{\text {out }}=\left.\dot{m}_{\text {stream }} \cdot c_{p, \text { stream }} \cdot \Delta T\right|_{\text {in }} ^{\text {out }} \\
\qquad=\dot{m}_{\text {stream }} \cdot c_{p \text {,stream }} \cdot T_{\text {in }} \cdot\left[\left(\frac{p_{\text {out }}}{p_{\text {in }}}\right)^{\frac{k-1}{k} \cdot \frac{1}{\eta_{p o l}}}-1\right] \\
\text { where the } k \text { is the specific heats ratio of the gaseous stream, } c_{p, \text { stream }} \text { is the } \\
\text { specific heat at constant pressure, } T_{\text {in }}(\mathrm{K}), p_{\text {in }} \text { and } p_{\text {out }} \text { are the inlet temperature, the } \\
\text { inlet pressure and outlet pressure, respectively, and } \eta_{\text {pol }} \text { is the polytropic efficiency } \\
(73 \% \text { and } 85 \% \text { for } \mathrm{C} 1 \text { and } \mathrm{C} 2 \text {, respectively). The Compressor } \mathrm{C} 2 \text { is intercooled. }\end{array}$ \\
\hline
\end{tabular}




\begin{tabular}{|l|} 
Catalytic burner \\
$\begin{array}{l}\text { This component is modeled by means of } R \text { Stoic that is a reactor in which the } \\
\text { stoichiometry is known. The combustion reactions is: } \\
\mathrm{H}_{2}+0.5 \mathrm{O}_{2} \rightarrow \mathrm{H}_{2} \mathrm{O}\end{array}$
\end{tabular}

The energy requirements and, as a consequence, the sizes of the refrigeration unit and of the hydrogen dispensing unit have been calculated by applying the first law of thermodynamics. In particular, the dispenser system has to be sized to refuel the vehicles according to the $\mathrm{SAE}$ J2601 fueling protocol that defines the hydrogen precooling temperature range $\left(-30 /-40^{\circ} \mathrm{C}\right)$; for avoiding the increase of the temperature during the vehicle tank refilling [10].

Thus, for calculating the required cooling power some assumptions have been made. These assumptions regard [10]:

- the station type/fuel delivery temperature: T40 (hydrogen is cooled at $-40^{\circ} \mathrm{C}$ )

- the station/hose delivery pressure: H70 (700 bar)

- the number of dispensers: 2 dispensers (one hose per dispenser)

- the fueling time: $5 \mathrm{~min}$

- the on-board average storage capacity: $5 \mathrm{~kg}$

The cooling power demand (Q_cool) of a dispenser during the vehicle fueling is:

$$
Q_{\text {cool }}=\dot{m}_{H 2, D} \cdot\left(h_{\text {storage }}-h_{\text {dispenser }}\right)
$$

where $\dot{m}_{H 2, D}$ is the hydrogen flow at the dispenser that is equal to $16.7 \mathrm{~g} / \mathrm{s}$ (the maximum hydrogen flow must be lower than $60 \mathrm{~g} / \mathrm{s}$ ), and $\mathrm{h}$ is the enthalpy at the storage temperature $\left(25^{\circ} \mathrm{C}\right)$ and at the temperature exiting the dispenser $\left(-40^{\circ} \mathrm{C}\right)$. The electric power supplied to the refrigeration facility is calculated by assigning a COP (coefficient of performance, assumed equal to 0.90$)$ :

$$
W_{\text {refrigerator }}=\frac{Q_{\text {cool }}}{C O P}
$$

Thus, the size of the refrigeration facility, for each hydrogen production capacity, has been calculated taking into account the both the fueling time $(5 \mathrm{~min})$ for each car and the number of dispensers.

\section{Energy Balance and performance results}

The sizing of the plant is based on the station hydrogen capacity $(200 \mathrm{~kg} / \mathrm{day})$ and the electric power requirements. These design specifications allowed to define the size of the ammonia cracking reactor, the heat exchangers, the PEMFC unit, the membrane separation unit as well as the cascade compression unit. In particular, the cascade system has been designed taking into account the tecno-economic results presented in ref. [11] in which it is concluded that, in order to minimize the compression energy consumption and the setup storage cost (number and volume of the storage banks), the best solution consists of 4 banks and the highestpressure bank has to be 4 times bigger in volume than the rest $(\mathrm{V} 1=\mathrm{V} 2=\mathrm{V} 3=\mathrm{V} 4 / 4)$. The 4 storage pressures, from the lowest to the highest, are 40 bar (Low Pressure, LP), 567 bar (Medium Pressure, MP), 733 (Medium-High Pressure, MHP) bar and 900 bar (High Pressure, HP), respectively. Otherwise, the sizes of the hydrogen storage tanks (low pressure, medium pressure, medium-high pressure and high pressure) have been calculated by following a 
storage strategy based on the hourly hydrogen refilling profile (fig. 1). According to this storage strategy, the hydrogen production has been assumed constant during the day (the related plant components and units work at nominal conditions), so that the difference between the hourly hydrogen production and the hourly hydrogen demand is balanced by the storage tanks. This means that when the hydrogen demand is greater than the hydrogen production, the deficit is covered by the stored hydrogen, while when there is a surplus between demand and production the excess hydrogen is stored. The initial time ( $\mathrm{t} 0$, expressed in hour), at which the storage starts (the stored hydrogen in the tanks is zero), is the parameter that allows to minimize the size of the storage tanks. This parameter, calculated by matching the hydrogen demand, the hydrogen production and the stored hydrogen (figure 3 ), is equal to hours 21:00. Results of the design and sizing activities are summarized in table 2. The maximum amount of the hydrogen that has to be stored is $77 \mathrm{~kg}$ (the calculated hydrogen amount has been increased of $10 \%$ in order to avoid the empty conditions). The described storage strategy allows the reduction of the total size of the tanks compared to the solution in which the stored hydrogen is that of the station hydrogen capacity $(1.27 \mathrm{~m} 3 \mathrm{vs} .3 .3 \mathrm{~m} 3)$. The total power consumption is $44.8 \mathrm{~kW}$; this electric power is supplied by the PEMFC that has an electric efficiency (referred to LHVH2) equal to $41.5 \%$. Moreover, the energy consumption for storing the hydrogen at 900 bar is equal to $6 \mathrm{kWh} / \mathrm{kg}$ of $\mathrm{H} 2$. The main characteristics of the plant streams are listed in table 3.

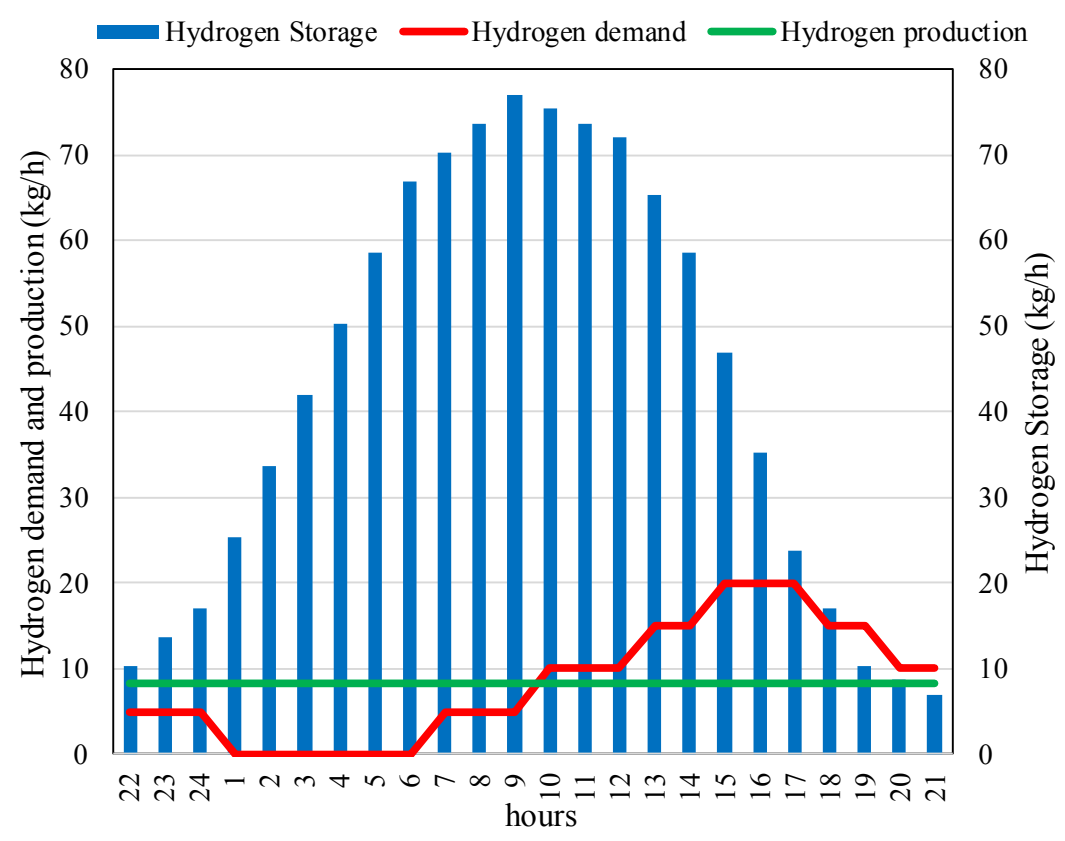

Fig.3. Matching of hydrogen demand, hydrogen production and hydrogen storage 
Table 2. Main operating data of the plant sections

\begin{tabular}{|c|c|c|c|c|}
\hline \multicolumn{3}{|l|}{ Plant Section } & & \\
\hline \multicolumn{3}{|c|}{ CRACKING SECTION } & & \\
\hline \multicolumn{3}{|c|}{ Reactor temperature $\left({ }^{\circ} \mathrm{C}\right)$} & \multicolumn{2}{|c|}{550} \\
\hline \multicolumn{3}{|c|}{ SEPARATION SECTION } & & \\
\hline \multicolumn{3}{|c|}{ Pd-Membrane Separation Unit } & \multirow{2}{*}{\multicolumn{2}{|c|}{0.80}} \\
\hline \multicolumn{3}{|c|}{ Hydrogen Recovery Factor, HRF } & & \\
\hline \multicolumn{3}{|c|}{ Feed/Permeate sides pressure (bar) } & \multicolumn{2}{|c|}{$3.67 / 1.1$} \\
\hline \multicolumn{3}{|c|}{ Operating Temperature $\left({ }^{\circ} \mathrm{C}\right)$} & \multicolumn{2}{|c|}{400} \\
\hline \multicolumn{3}{|c|}{ Modules Number/ Module Tubes Number } & \multicolumn{2}{|c|}{$10 / 20$} \\
\hline \multicolumn{3}{|l|}{ Tube area $\left(\mathrm{m}^{2}\right)$} & \multicolumn{2}{|c|}{0.0385} \\
\hline \multicolumn{3}{|l|}{ Total area $\left(\mathrm{m}^{2}\right)$} & \multicolumn{2}{|c|}{77} \\
\hline \multicolumn{3}{|l|}{ Compressor $C 1$} & \\
\hline \multicolumn{3}{|l|}{ Pressure ratio } & \multicolumn{2}{|c|}{3.6} \\
\hline \multicolumn{3}{|c|}{ Electric power $(\mathrm{kW})$} & \multicolumn{2}{|c|}{12.14} \\
\hline \multicolumn{3}{|l|}{ Compressor C2 } & \\
\hline \multicolumn{3}{|l|}{ Pressure ratio } & \multicolumn{2}{|c|}{20.0} \\
\hline \multicolumn{3}{|c|}{ Electric power $(\mathrm{kW})$} & \multicolumn{2}{|c|}{14.96} \\
\hline \multicolumn{5}{|c|}{ HYDROGEN COMPRESSION AND STORAGE SECTION } \\
\hline & $\begin{array}{l}\text { Compressor } \\
L P\end{array}$ & $\begin{array}{l}\text { Compressor } \\
M P\end{array}$ & $\begin{array}{c}\text { Compressor } \\
\text { MHP }\end{array}$ & $\begin{array}{c}\text { Compressor } \\
H P\end{array}$ \\
\hline Pressure ratio & 20.0 & 1.41 & 1.30 & 1.23 \\
\hline $\begin{array}{l}\text { Electric power } \\
(\mathrm{kW})\end{array}$ & 14.22 & 1.6 & 1.14 & 0.78 \\
\hline $\begin{array}{l}\text { Volume LP } \\
\text { tank (m3) }\end{array}$ & 0.18 & 0.18 & 0.18 & 0.73 \\
\hline HYDROGEN & FRIGERATIC & AND DISPEN & ING SECTIO & \\
\hline Cooling temper & Ire $\left({ }^{\circ} \mathrm{C}\right)$ & & & \\
\hline Electric power & isumption $(\mathrm{kW}$ & & & \\
\hline POWER SEC & & & & \\
\hline PEMFC power & it $(\mathrm{kW}) \mathrm{DC} / \mathrm{AC}$ & & & 44.8 \\
\hline Stacks number/ & ells number x s & & & \\
\hline Active cell area & $\left.\mathrm{m}^{2}\right)$ & & & \\
\hline Average stack & tage/Current de & sity $\left(\mathrm{V} / \mathrm{A} \mathrm{cm}^{-2}\right)$ & & $/ 0.2$ \\
\hline Stacks Temper & $\mathrm{re}\left({ }^{\circ} \mathrm{C}\right)$ & & & \\
\hline $\mathrm{U}_{\mathrm{F}}$ & & & & \\
\hline
\end{tabular}

Table 3. Operating data of the main streams

\begin{tabular}{|c|c|c|c|c|}
\hline Stream & $\begin{array}{c}\text { Composition }(\% \\
\text { vol) }\end{array}$ & $\begin{array}{c}\text { Mass flow } \\
(\mathbf{k g} / \mathbf{h})\end{array}$ & $\begin{array}{c}\text { Temperature } \\
\left({ }^{\circ} \mathbf{C}\right)\end{array}$ & $\begin{array}{c}\text { Pressure } \\
(\text { bar })\end{array}$ \\
\hline $\mathbf{1}$ & $100 \mathrm{NH}_{3}$ & 77.25 & 20.0 & 8.8 \\
\hline $\mathbf{4}$ & $100 \mathrm{NH}_{3}$ & 77.25 & 279 & 1.1 \\
\hline $\mathbf{5}$ & $74.9 \mathrm{H}_{2}, 24.9 \mathrm{~N} 2$ & 77.25 & 550 & 1.1 \\
\hline $\mathbf{0 . 2 \mathrm { NH } _ { 3 }}$ & & & 67 & 1.1 \\
\hline $\mathbf{8}$ & $75 \mathrm{H}_{2}, 25 \mathrm{~N}_{2}$ & 77.02 & 67 & 1.1 \\
\hline $\mathbf{9}$ & $75 \mathrm{H}_{2}, 25 \mathrm{~N}_{2}$ & 18.34 & 67 & 1.1 \\
\hline $\mathbf{1 0}$ & $75 \mathrm{H}_{2}, 25 \mathrm{~N}_{2}$ & 58.68 & 400 & 3.67 \\
\hline $\mathbf{1 2}$ & $75 \mathrm{H}_{2}, 25 \mathrm{~N}_{2}$ & 58.68 & 400 & 1.1 \\
\hline $\mathbf{1 3}$ & $100 \mathrm{H}_{2}$ & 8.33 & 64 & 1.1 \\
\hline $\mathbf{1 4}$ & $100 \mathrm{H}_{2}$ & 8.33 & 235 & 20 \\
\hline $\mathbf{1 5}$ & $100 \mathrm{H}_{2}$ & 8.33 & & \\
\hline
\end{tabular}




\begin{tabular}{|c|c|c|c|c|}
\hline $\mathbf{1 7}$ & $62.5 \mathrm{~N}_{2}, 37.5 \mathrm{H}_{2}$ & 15.74 & 67 & 1.1 \\
\hline $\mathbf{1 8}$ & $100 \mathrm{Air}$ & 177.54 & 25 & 1.1 \\
\hline $\mathbf{1 9}$ & $\begin{array}{c}11.3 \mathrm{O}_{2}, 78.6 \mathrm{~N}_{2}, \\
10.1 \mathrm{H}_{2} \mathrm{O}\end{array}$ & 367.28 & 972 & 1.01 \\
\hline $\mathbf{2 0}$ & $\begin{array}{c}11.3 \mathrm{O}_{2}, 78.6 \mathrm{~N}_{2}, \\
10.1 \mathrm{H}_{2} \mathrm{O}\end{array}$ & 367.28 & 290 & 1.01 \\
\hline $\mathbf{2 2}$ & $\begin{array}{c}11.3 \mathrm{O}_{2}, 78.6 \mathrm{~N}_{2}, \\
10.1 \mathrm{H}_{2} \mathrm{O}\end{array}$ & 367.28 & 169 & 1.01 \\
\hline $\mathbf{2 5}$ & $100 \mathrm{H}_{2}$ & 0.63 & 35 & 400 \\
\hline $\mathbf{2 6}$ & $100 \mathrm{H}_{2}$ & 0.89 & 35 & 565 \\
\hline $\mathbf{2 7}$ & $100 \mathrm{H}_{2}$ & 1.15 & 35 & 733 \\
\hline $\mathbf{2 8}$ & $100 \mathrm{H}_{2}$ & 5.66 & 35 & 900 \\
\hline
\end{tabular}

\section{Economic analysis}

The economic analysis has been carried out by using the results of the energy analysis that refers to steady-state operation and nominal operating conditions of the proposed plant. In order to define the economic feasibility, according to the design and the development of novel refueling stations for FCEVs, the analysis has been performed by estimating the Capital Expenditure (CAPEX), the Operational Expenditure (OPEX), the Replacement Expenditure (REPLEX), and then by calculating the levelized cost of hydrogen LCOH that is the more important indicator among the economic evaluation indexes.

\subsection{Cost assessment}

Table 4 summarizes the CAPEX, OPEX and REPLEX of the main plant components. These costs have been obtained by means of economic data available in the scientific literature. The capital cost of the NH3 cracking unit has been derived from the study of Lee et al [12]. In particular, in determining the cost of this unit more components have been taken into account: reactor, burner, storage tank, insulator and external materials. Thus, it results that the specific (related to hydrogen production capacity, $\mathrm{kg} / \mathrm{h}$ ) capital cost is $4.28 \mathrm{k} €$. The capital cost of the PEMFC unit (5 stacks) has been derived from the data reported in [13] and taking into account the manufacturing and $\mathrm{BoP}$ costs for $10 \mathrm{~kW}$ stack and assuming a production volume of 10000 units. (i.e. air supply for cathode, DC/AC inverter, instrumentation and control, assembly components and additional work). The unit cost of the PEMFC power section results $1330 € / \mathrm{kW}$. For the compressors, the CAPEX has been calculated by using the following equation:

$$
C_{\text {compressor }}=36079.54 \cdot W^{0.6038}
$$

where $W(\mathrm{~kW})$ is the installed power.

For the LP and MP storage tanks and the MHP and HP storage tanks the CAPEX have been set to 1.081 and $1.622 \mathrm{k} €$, respectively [11] while for the refrigerator, a capital cost equal to $5.37 \mathrm{k} € / \mathrm{kW}$ has been considered [4].

The OPEX of each component of the plant have been calculated as a percentage of the capital expenditure, according to values reported in the scientific literature. Moreover, further two operating costs have been considered: the ammonia cost and the electricity cost. In the first case the ammonia price has been assumed equal to $450 € / \mathrm{t}$ as proposed in Ref.[14]. With 
respect to the electricity, three prices (taxes included) have been considered, according to the Italian electricity market in which there are three time slots $(0.137 € / \mathrm{kWh}, 0.134 € / \mathrm{kWh}$ and $0.119 € / \mathrm{kWh}$ for F1, F2 and F3 time slots, respectively [15]).

With referring to the Replacement Expenditure (REPLEX), the components that have to be replaced during the plant lifetime (20 years) are the PEMFC stacks, the reactor catalysts, the compressors and the hydrogen dispensers. For the PEMFC, as well as for the reactor catalyst, a lifetime of 40000 hours has been considered, like in Ref. $[9,16]$, while for the compressors and for the hydrogen dispensers, a replacement time of 10 years is assumed [17].

Table 4. CAPEX, OPEX and REPLEX

\begin{tabular}{|c|c|c|c|c|}
\hline Plant Section & CAPEX & \multicolumn{2}{|c|}{ OPEX } & REPLEX \\
\hline NH3 CRACKING SECTION & $(\mathrm{k} €)$ & $\begin{array}{c}(\% \text { of } \\
\text { CAPEX) }\end{array}$ & $(\mathrm{k} €)$ & $(\mathrm{k} €)$ \\
\hline Cracker \& Auxiliaries & 58.7 & 3 & 1.8 & 27.0 \\
\hline POWER SECTION & & & & \\
\hline PEMFC unit \& Auxiliaries & 62.5 & 5 & 3.1 & 26.9 \\
\hline SEPARATION SECTION & & & & \\
\hline Compressor C1 & 166.6 & 8 & 13.3 & 166.6 \\
\hline Pd Membrane & 60.9 & 2.67 & 1.6 & - \\
\hline $\begin{array}{c}\text { HYDROGEN COMPRESSION } \\
\text { AND STORAGE SECTION }\end{array}$ & & & & \\
\hline Compressor C2 & 185.1 & 8 & 14.8 & 185.1 \\
\hline Compressor LP & 179.1 & 8 & 14.3 & 179.1 \\
\hline Compressor MP & 47.9 & 8 & 3.8 & 47.9 \\
\hline Compressor MHP & 40.3 & 8 & 3.2 & 40.3 \\
\hline Compressor HP & 31.5 & 8 & 2.5 & 31.5 \\
\hline LP\&MP_Storage & 13.8 & 3 & 0.4 & - \\
\hline MHP\&HP_Storage & 92.8 & 3 & 2.8 & - \\
\hline $\begin{array}{c}\text { HYDROGEN REFRIGERATION } \\
\text { AND DISPENSING SECTION }\end{array}$ & & & & \\
\hline Refrigerator & 182.7 & 3 & 5.5 & - \\
\hline Heat Exchangers & 72.5 & 3 & 2.2 & - \\
\hline Dispensers & 130.0 & 3 & 3.9 & 130.0 \\
\hline TOTAL (K€) & $\mathbf{1 3 2 4 . 4}$ & - & $\mathbf{7 3 . 3}$ & $\mathbf{8 3 4 . 4}$ \\
\hline
\end{tabular}




\subsection{Levelized cost of hydrogen calculation}

The levelized cost of hydrogen is calculated as:

$$
L C O H=\frac{\text { Total Costs }(€)}{H_{2} \text { Annual Production }(\mathrm{kg})}=\frac{C_{i n v, a}+C_{r e p, a}+C_{O \& M}}{M_{H_{2}}}
$$

The annual capital repayment $\left(\mathrm{C}_{\text {inv,a }}\right)$ [18] calculated by considering the total plant capital investment costs $\left(\mathrm{C}_{\mathrm{inv}}\right)$, the plant economic lifetime $(\mathrm{n})$ equal to 20 years, and the nominal interest rate (i) assumed equal to $3 \%$ [19] is:

$$
C_{i n v, a}=\frac{i \cdot(1+i)^{n}}{(1+i)^{n}-1} \cdot C_{i n v}
$$

The annualized replacement $\operatorname{cost}\left(C_{r e p, a}\right)$ is defined as:

$$
C_{r e p, a}=\frac{i \cdot(1+i)^{n}}{(1+i)^{n}-1} \cdot \frac{C_{r e p}}{(1+i)^{t}}
$$

where $C_{r e p}$ is the replacement cost, $\mathrm{t}$ is the year of the replacement. $C_{O \& M}$ is the annual operating and maintenance cost. In this term the annual cost of the consumed ammonia is counted.

Starting from the costs assessment and by applying eqs 14-16 the LCOH for the proposed plant results $7.35 € / \mathrm{kg}$. The operational and maintenance costs are the main contributor $(72.2 \%)$ to the $\mathrm{LCOH}$ while the investment costs impact with the $18.2 \%$.

\subsection{Comparison with electrical energy supply by grid}

In the proposed plant the electric energy demand is satisfied by the PEMFC unit. In order to evaluate the influence of this technology cost on the $\mathrm{LCOH}$, two further modes of supplying have been considered. These modes refer to: i) PEMFC and grid-supplied electricity (PEMFC/grid mode) in which the grid provides electric power during the hours in which the electricity price is the lowest (according to the time slots of the Italian electricity market); full grid-supplied electricity (Grid mode) in which the PEMFC unit is not more a plant's component. In the PEMFC/grid mode the electric energy demand is satisfied for 4560 hours (on 8000 hours per year) by the PEMFC unit and for the remaining time by the grid. This operation time is calculated taking into account the time slots [15]. The LCOH has been calculated by applying eqs 14-16. Figure 4 shows the LCOH for all the studied plant configurations. LCOH values range from $7.35 € / \mathrm{kg}$ to $6.92 € / \mathrm{kg}$ as shown in figure 4 .

It can be noted that, even if the best economic solution is based on the full grid-supplied electricity operation (Grid mode) the gap with respect to the PEMFC mode is very small and considering the expected decreasing in the cost of PEMFC unit due to the increasing of the 
production volume in the near future, it can be affirmed that the proposed on-site refueling station will represent an interesting configuration for the hydrogen delivery.

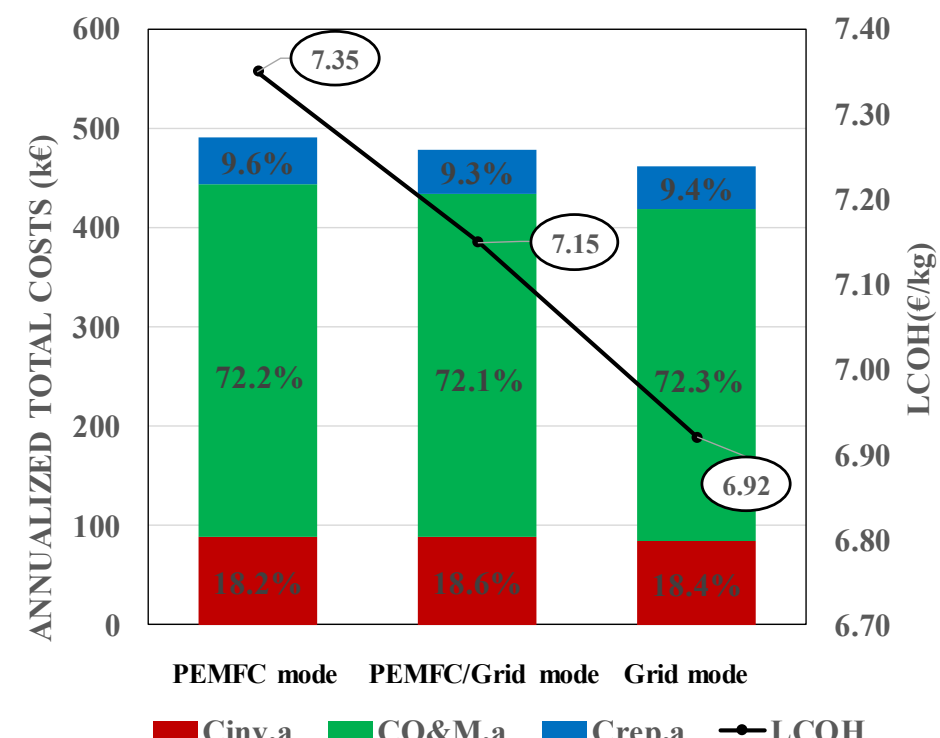

FIGURE 4. LCOH comparison in different modes of electricity supply

\section{Conclusion}

The present work is focused on the energy and economic analyses of a small-medium size hydrogen refueling station based on the ammonia as hydrogen carrier. The station is designed with a modular configuration consisting of more sections: i) the hydrogen production section based on ammonia cracking, ii) the electric energy supplier section based on PEMFC technology, iii) the hydrogen separation section based on Pd-Ag membrane technology, iv) the hydrogen storage section and the refrigeration/dispenser section. The main sizing results concern the PEMFC power unit $(46.7 \mathrm{~kW})$, the Pd-Ag membrane separation unit $\left(7.7 \mathrm{~m}^{2}\right)$ and the hydrogen storage tanks $\left(1.27 \mathrm{~m}^{3}\right)$. From the economic point of view, the calculated $\mathrm{LCOH}$ equal to $7.35 € / \mathrm{kg}$, is a promising result for the development of the hydrogen-based mobility.

\section{References}

[1] M. Minutillo, A. Perna, P. Di Trolio, S. Di Micco, E. Jannelli, Undrer Press, Int J Hydrog. Energy (2020).

[2] A. Perna, M. Minutillo, E. Jannelli, V. Cigolotti, SW. Nam, J. Han, et al. Appl Energy,36:11128-36 (2011).

[3] J. Cha , Jo YS, H. Jeong, J. Han, SW. Nam, KH. Song, et al. Appl Energy, 224:192-204 (2018). 
[4] K. Reddi, A. Elgowainy, N. Rustagi,E. Gupta, Int J Hydrog. Energy, 42:21855-65 (2017).

[5] MF. Ezzat, I. Dincer, Int. J. Hydrog. Energy, 43: 4597-4608 (2018).

[6] Kim J.. J Electrochem Soc 1995. https://doi.org/10.1149/1.2050072.

[7] E. Jannelli, M. Minutillo, A. Perna, Appl Energy, 108: 82-91 (2013).

[8] M. Minutillo, A. Perna, A. Sorce, Int J Hydrog Energy, 44:23880-98 (2019).

[9] A. Perna, SP. Cicconardi, R. Cozzolino, Int J Hydrog Energy, 36: 9906-9915 (2011).

[10] K. Reddi, A. Elgowainy, N. Rustagi,E. Gupta, Int J Hydrog Energy, 42: 1667516685(2017).

[11] C. Blazquez-Diaz, Int J Hydrogen Energy, 44: 495-510(2019).

[12] B. Lee, J. Park, H. Lee, M, Byun, CW. Yoon, H. Lim, Renew Sustain Energy Rev, 113: 109262 (2019).

[13] Battelle Memorial Institute. (2017).

https://www.energy.gov/sites/prod/files/2018/02/f49/fcto_battelle_mfg_cost_analysis_1\%2 0 to_25kw_pp_chp_fc_systems_jan2017_0.pdf.

[14] A. Boulamanti, JA. Moya JA, Renew Sustain Energy Rev,68:1205-12 (2017).

[15] Condizioni economiche per i clienti del servizio di maggior tutela2020https://www.arera.it/it/dati/condec.htm.

[16] I. Staffell, R. Green, Int J Hydrog Energy, 38:1088-102 (2013).

[17] Department of energy (DOE). https://www.energy.gov/eere/fuelcells/doe-technicaltargets-hydrogen-delivery.

[18] L. Viktorsson, JT. Heinonen, JB. Skulason, R. Unnthorsson, .Energies, 10:1-15 (2017).

[19] AS. Mehr, M. Gandiglio, M. MosayebNezhad, A. Lanzini, SMS. Mahmoudi, M. Yari, et al.. Appl Energy, 191:620-38 (2017). 